\title{
ANAK NAKAL: DIVERSI DAN DILEMA PENERAPANNYA
}

\author{
Eva Achjani Zulfa ${ }^{1}$
}

\begin{abstract}
Abstrak
Handling problems through brat children and children who have problems with the law have occurred again when some kids sticking a gamble being arrested at near Soekarno Hatta Airport areas then processed into the judicial process. Diversion is a form of change the process by which a program can only take place on hold pre-adjudication in the criminal justice system. Forms of transfer or diversion of this case are indeed associated with the authority possessed discretion of law enforcement officers. Giddiness has appeared in the process of implementation of diversion by law enforcement officials, the search for forms of application of the criminal case handling child has become a growing discourse management. Policy taken toward the institution of criminal diversion not only becomes demand for law enforcement officers, but also must be institutionalized through plain legal mechanisms. It becomes author's concern to create more certain procedures to brighten solve on deviant children in this way
\end{abstract}

Kata kunci: hukum pidana, anak nakal, diversi, dilemma penerapan

\section{Pendahuluan}

Setelah kasus Mohammad Azwar alias Raju, bocah berusia delapan tahun yang diadili Pengadilan Negeri (PN) Langkat, Sumatera Utara, karena berkelahi dengan seorang anak lain pada 2006, kini kasus persidangan anak kembali mendapat sorotan. PN Tangerang, Banten menyidangkan 10 orang anak yang masih di bawah umur dengan dugaan melakukan permainan koin dengan taruhan uang senilai Rp1.000. Kesepuluh anak yang masih duduk di bangku sekolah dasar dan sekolah menengah pertama itu didakwa telah melanggar Pasal 303 Kitab Undang-Undang Hukum Pidana (KUHP) oleh jaksa penuntut umum. Anak-anak yang sehari-hari menjadi penyemir sepatu di bandara itu ditangkap Kepolisian Resor Khusus Bandara Internasional Soekarno-Hatta pada akhir Mei lalu karena bermain "macan buram" atau

${ }^{1}$ Pengajar tetap Fakultas Hukum Universitas Indonesia dan Sekertaris Bidang Studi Hukum Pidana FHUI. Alamat korespondensi: qorymail@yahoo.com. 
permainan tradisonal menggunakan koin. Mereka yang tinggal di Desa Rawarengas, Kecamatan Kosambi yang terletak tepat di belakang bandara itu pun harus menginap di Lembaga Pemasyarakatan (Lapas) Anak Pria Tangerang selama menjalani proses hukum di kepolisian.

Masalah penanganan anak nakal dan anak yang bermasalah dengan hukum kembali mencuat ketika beberapa anak yang tertangkap bermain judi disekitar bandara Soekarno Hatta dibawa kedalam proses peradilan. Sejumlah pertanyaan mencuat kemudian benarkah tindakan petugas penegak hukum dalam menangani perkara tersebut?

Mengacu kepada ketentuan peraturan perundang-undangan, pada dasarnya apa yang dilakukan oleh para petugas bukan merupakan sesuatu hal yang bertentangan. Undang-undang No.3 tahun 1997 memperkenankan anakanak yang berusia diatas 8 tahun untuk diproses dalam sistem peradilan pidana. Akan tetapi yang benar menurut kacamata undang-undang tersebut apakah sudah tepat bagi penanganan anak-anak? Apakah penanganan model kasus diatas akan membawa kebaikan bagi anak?

Barangkali menarik kalau model penanganan diatas kita bandingkan dengan ilustrasi kasus berikut:

Alex (15 tahun/bukan nama sebenarnya) pada suatu hari dibulan Agustus 2005 mendatangi Pak Nasrun (bukan nama sebenarnya) dan meminta izin untuk meminjam sepeda merk federal yang sedang terparkir didepan pekarangannya. Tanpa mencurigai adanya itikad buruk, Pak Nasrun pun memberikan izin. Namun sampai malam tiba sepeda tersebut tak kunjung kembali. Esoknya Pak Nasrun pun mendatangi orangtua Alex, tapi yang didapatinya hanya khabar bahwa Alex sudah sebulan tak pulang ke rumah disertai permohonan maaf. Belakangan Pak Nasrun pun mendapat informasi bahwa tindakan itu sudah sering dilakukan terhadap orang lain. Sekali lagi Pak Nasrun datang kerumah Alex. Pada saat itulah ia mendapatkan pengakuan bahwa tindakan Alex merupakan upaya sang anak untuk melunasi hutang orangtuanya. Pak Nasrun yang merasa dirugikan, tidak begitu saja memberikan maaf. Atas permintaan orangtua Alex (dan juga dengan pertimbangan tidak mau direpotkan untuk berurusan dengan petugas kepolisian), ia meminta agar orangtuaAlex membayar uang seharga sepeda yang dipinjam Alex, bila tidak maka ia akan melaporkannya pada pihak berwajib. Dan dalam hal ini, pihak orangtua pun membayarkan biaya tersebut dan Pak Nasrun pun menyatakan kasus selesai. 
Atau dalam ilustrasi kasus berikut:

Jaka (bukan nama sebenarnya) bocah yang tinggal disebuah perkampungan kumuh yang terletak di pinggir sebuah perumahan Griya Bumi Asri 3 (selanjutnya disebut GBA3) bersama ibu dan ayah yang pekerjaan sehari-harinya adalah mengayuh becak. Namun Jaka bukan anak yang kurang pergaulan, tak sungkan penduduk yang tinggal di GBA3 meminta bantuannya atau ibunya. Setelah 4 tahun tinggal dan bergaul dilingkungan tersebut, tersebarlah berita kemalingan di lingkungan kompleks yang kerap terjadi dalam kurun waktu 2 (dua) tahun terakhir. Salah satu korbannya adalah pak Erli, salah seorang penduduk komplek GBA 3 yang kehilangan handphone dan beberapa lembar uang. Berikutnya Pak Yogi, yang tiga kali berturut-turut disatroni maling yang masuk lewat celah atap genting yang berada dikamar mandi. Anehnya yang dicuri justru kencleng Uang PKK dan celengan anaknya, sementara laptopnya tetap berada ditempat. Namun setelah Pak Yogi menulis peringatan di kamar mandinya, sang maling menghentikan aksinya. Jaka kemudian tertangkap sedang meloncati rumah Pak Pendi. ${ }^{2}$

Mengacu kepada kasus diatas, apakah kedua model penanganan dalam kedua kasus diatas lebih baik dibandingkan dengan model penanganan dalam kasus anak di Tangerang.

Bila dilakukan suatu evaluasi secara sederhana, kelemahan utama model penanganan anak dalam kasus di Tangerang adalah bahwa proses dalam sistem peradilan pidana dipercaya selalu membawa dampak buruk bagi anak. Anak yang berkumpul dengan orang dewasa yang merupakan pelanggar hukum dan anak-anak dalam kualifikasi pelanggar hukum dianggap justru akan memicu anak menjadi lebih buruk dibandingkan dengan sebelum ia diproses dalam sistem peradilan pidana. Belum lagi stigma negatif yang melekat padanya.

Sementara model penanganan dalam kasus Alex dan Jaka, juga bukan merupakan model penanganan yang baik. Dengan melepaskan anak dari beban tanggungjawab atas pelanggaran hukum yang dibuatnya, maka tidak

${ }^{2}$ Sandi Ibrahim Abdillah, Antara Pengusiran dan Pemenjaraan, Jurnal Restorasi, Edisi 9 Vol. IV Tahun 2008, hal. 30-40. 
ada satu upaya perbaikan yang dapat menanamkan kesadaran pada anak bahwa perbuatan yang dilakukannya adalah keliru dan tidak baik.

Karenanya mengacu kepada dua kasus diatas, memasukkan anak dalam proses peradilan pidana atau membebaskan anak dari proses peradilan pidana sama sekali harus dilihat dalam kacamata positif yaitu apakah tindakan memasukkan atau membebaskannya dari proses merupakan suatu tindakan yang akan membawa kebaikan bagi anak tersebut. Karenanya dibutuhkan suatu model penanganan perkara pidana yang dilakukan bagi anak yang tentunya berbeda dengan penanganan bagi orang dewasa yang tentunya dapat mencapai tujuan utama yaitu edukasi bagi anak yang bermasalah dengan hukum.

\section{Makna Diversi}

Wacana diversi mengemuka dalam berbagai diskusi dalam upaya mencari model penanganan perkara pidana yang dilakukan oleh anak. Perkembangan praktek dilapangan, aparat penegak hukum mencoba mewadahi kekurangan yang ada dalam hukum pidana formil tersebut diatas melalui lembaga diversi. ${ }^{3}$ Konsep diversi dalam Black Law Dictionary diterjemahkan sebagai Divertion Programme yaitu:

A program that refers certain criminal defendants before trial to community programs on job training, education, and the like, which if successfully completed may lead to the dismissal of the charges. ${ }^{4}$

(program yang ditujukan kepada seorang tersangka sebelum proses persidangan berupa community programme seperti pelatihan kerja, pendidikan dan semacamnya dimana jika program ini dianggap berhasil memungkinkan dia untuk tidak melanjutkan proses peradilan pidana selanjutnya).

${ }^{3}$ BPHN, Draft Akademis RUU Peradilan Anak, (Jakarta: BPHN,2007), hal. 67. definisi ini juga terdapat dalam Manual Pelatihan Untuk Polisi, Proyek Kerjasama UNICEF dan POLRI, 2004, hal. 330. 387.

${ }^{4}$ Bryan A. Garner (ed), Black's Law Dictionary, (Minnessota: St.Paul, 2000), 
Dalam Black Law Dictionary tersebut, diversi adalah bentuk pengalihan proses dimana merupakan program yang hanya dilakukan pada tahan pra ajudikasi dalam sistem peradilan pidana. Bentuk pengalihan perkara atau diversi ini biasanya memang berhubungan dengan kewenangan diskresi yang dimiliki aparat penegak hukum. Dengan definisi dalam Black Law Dictionary tersebut, makna diversi seolah-olah hanya menjadi milik polisi saja melalui kewenangan diskresi yang dimilikinya.

Dalam hubungannya dengan pengalihan proses perkara pidana, kata diskresi kerap dihubungan dengan polisi saja sementara kata opportunitas dihubungkan dengan jaksa. Namun tidak demikian dengan Aronson menyatakan bahwa discretion designates power or freedom to judge and decide what need to be done in a particular situation. ${ }^{5}$ Sementara Kenneth Davis menyatakan bahwa diskresi merupakan bagian dari alat yang dipakai oleh petugas dalam bidang administrasi pemerintahan, dalam hal ini ia memasukkan polisi, jaksa dan hakim sebagai bagian dari petugas administrasi Negara. Aronson menggambarkan bahwa makna diskresi meliputi tindakan menginterpretasikan undang-undang, penggunaan kewenangan dan pilihan tindakan dari penegak hukum.

Ronald F Wright menyatakan bahwa diskresi bagi jaksa merupakan kewenangan untuk memilih dan menentukan penuntutan dari suatu perkara dan menentukan jenis, berat atau lamanya sanksi yang akan dituntut. ${ }^{6}$ Sementara diskresi dalam istilah yang dipakai oleh Heffernan dan Stroup merupakan hard choices in law enforcement (meskipun dalam tulisannya titik berat pilihan penggunaan diskresi ada pada polisi sebagai pintu gerbang sistem peradilan pidana). ${ }^{7}$

Dinyatakan sebagai pilihan yang berat karena apa yang ditentukan dalam aturan tertulis dibandingkan dengan situasi yang nyata dalam realitanya bisa jadi sangat berbeda. Adanya perbedaan antara konsep ideal yang ditentukan secara formal dalam aturan perundang-undangan dengan situasi yang berbeda dalam realitasnya, menyebabkan petugas harus mengambil kebijakan menurut pertimbangannya sendiri sebagai respon atas

${ }^{5}$ David E. Aronson., Thomas Dienes dan Machael C. Musheno, "Public Policy And Police Discretion Processes of Decriminalization", (New York: Clark Boardman CO, 1984) hal. 5.

${ }^{6}$ Ronald F Wright dan Rodnef F. Langen, The Effective Of Depth and Distance in a Criminal Code on Charging, Sentencing And ProsecutorPower, North California Law Review Vol. 84 tanggal 15 September 2006, hal. 1942-1943.

${ }^{7}$ William C Heffernan dan Timothy Stroup (eds), "Police Etics: Hard Choices in Law Enforcement", (New York: John Jay Press, 1985). 
situasi tersebut. Oleh karenanya kewenangan diskresi sebagai alat untuk melakukan diversi dalam proses peradilan pidana dapat dilakukan oleh hakim, jaksa, polisi dan petugas pemasyarakatan sebagai bagian dari sub sistemnya.

Van Ness menggambarkan bahwa polisi membutuhkan tindakan diskresi dalam rangka memutuskan tindakan yang dilakukan dalam perkara pidana anak atau orang-orang dewasa dalam kasus-kasus tertentu. Tindakan diversi baru dapat dilakukan manakala kewenangan melakukan diskresi meliputi juga tindakan pengalihan perkara atas dasar-dasar tertu yang diperkenankan. ${ }^{8}$ Di New Zealand, The Children, Young Persons and Their Families Act 1989 mengizinkan polisi untuk melakukan musyawarah dengan keluarga sebagai upaya alternatif penyelesaian perkara dengan menggunakan pendekatan restoratif.

Jaksa pun menggunakan opportunitasnya atas dasar kewenangan diskresi yang dimilikinya dalam memutuskan apakah suatu perkara diteruskan untuk dilakukan penuntutan atau tidak. Sebagai contoh di New Zealand, dalam Resource Management Act 1991 and Building Act 1991/2004 dinyatakan bahwa dalam penanganan tindak pidana lingkungan jaksa dapat melakukan pengalihan proses dengan beberapa kriteria perkara yang ditentukan dalam kedua undang-undang tersebut.

Bagi hakim kewenangan diskresi dalam memutuskan bentuk pemidanaan seperti apa yang dapat diterapkan atau kah ada upaya lain selain daripada memidana pelaku. New Zeland the Children, Young Persons, and their Families Act $1989^{\circ}$ dan Youth Justice and Criminal Evidence Act, $1999^{10}$ yang berlaku di Inggris, kewenangan yang diberikan oleh undangundang ini adalah memberikan keleluasaan untuk mencari model tindakan yang dapat diterapkan bagi terpidana anak.

Khusus bagi diversi yang diterapkan dalam kasus anak, dibanyak negara diversi dilakukan sebagai upaya pengalihan penanganan kasus-kasus anak yang diduga telah melakukan tindak pidana dari proses formal dengan atau tanpa syarat. Diversi dalam hal ini bertujuan untuk: ${ }^{11}$

${ }^{8}$ Daniel Van Ness, An Overview Restortive Justice Around The World, makalah disampaikan pada United Nation $11^{\text {th }}$ congress on Crime Prevention and Criminal Justice, Bangkok Thailand, 22 April 2005, hal. 8.

${ }^{9}$ Ministery of Social Develompent, "Safeguarding our children: Updating the Children, Young Persons, and their Families Act 1989", (Wellington-New Zealand, 2 Agustus 2007).

${ }^{10}$ Youth Justice and Criminal Evidence Act, 1999, UK Parliament. 
1. Menghindari penahanan;

2. Menghindari cap/label sebagai penjahat;

3. Memajukan intervesi-intervensi yang dibutuhkan korban dan pelaku tanpa melalui proses formal;

4. Menghindari anak mengikuti proses peradilan pidana dalam rangka menghindari pengaruh dan implikasi negatif dari proses tersebut.

Dalam pencapaian tujuan terakhir, maka upaya ini lebih sering dilakukan ditingkat kepolisian oleh polisi dengan menggunakan kekuasaan diskresinya (power of discretion). Di lembaga kejaksaan, pengesampingan prosedur ini dilakukan melalui lembaga opportunitas dengan jalan mendeponer suatu perkara.

\section{Penerapan Diversi di Selandia Baru dan Philippina}

\section{A. Selandia Baru}

Dalam perkembangannya pada tahun 1989 , pemerintah Selandia Baru mensyahkan the Children, Young Persons and Their Family Act. ${ }^{12}$ Keberadaan undang-undang ini penting sebagai panduan para petugas kepolisian dalam penanganan perkara pidana yang pelakunya adalah anak atau remaja. Dalam tindak pidana yang pelakunya adalah orang dewasa, dampak buruk yang di khawatirkan dari proses peradilan pidana yang dijalani adalah stigma negatif. Akan tetapi masuknya seorang anak ke dalam sistem peradilan pidana lebih dari stigma negatif tersebut. Lembaga-lembaga yang tergabung dalam sistem peradilan pidana bukanlah tempat yang baik bagi tumbuh kembangnya seorang anak. Oleh karenanya dalam undang-undang tersebut bukan hanya dikedepankan tentang tujuan umum dari penggunaan pendekatan keadilan restoratif, akan tetapi undang-undang tersebut juga memberikan landasan bagi penyelesaian perkara pidana secara cepat bagi kasus pidana dengan pelaku anak.

${ }^{11}$ Dalam Barangay Justice System yang diterapkan di Philippina dan di New Zeland dalam Undang-undang peradilan anaknya, pertimbangan ini merupakan dasar dari pilihan penerapan keadilan restoratif. Ministery of Social Develompent, $O p$. Cit., ketentuan ini juga terdapat diberbagai Negara lain.

12 Ministery of Social Develompent, Safeguarding our children: Updating the Children, Young Persons, and their Families Act 1989, (Wellington-New Zealand, 2 Agustus 2007). 
Polisi yang menangani perkara pidana di Negara ini, memiliki 4 (empat) tahapan penanganan yang dapat diterapkan pada tersangka/terdakwa anak, yaitu ${ }^{13}$ (1) mereka dapat menggunakan peringatan secara informal; (2) peringatan tertulis;(3) merancang sebuah program dalam kerangka program diversi; dan (4) merancang sebuah family group conferences (meskipun belum ada proses pembuktian dalam sidang pengadilan anak).

Meskipun mekanisme sebagaimana tersebut diatas diperkenankan, namun polisi tetap saja diminta untuk melihat perkara pidana dari beberapa sisi sebagai pertimbangan apakah tahapan penanganan tersebut diatas dapat diterapkan kepada anak dengan mempertimbangkan tingkat keseriusan tindak pidana yang dilakukan, catatan kejahatan di kepolisian serta lingkungan keluarga dimana si anak ini hidup. ${ }^{14}$

Dari catatan dan evaluasi yang dibuat oleh Gabrielle Maxwell dan kawan-kawan tercatat $17 \%$ dari kasus yang dijadikan sampel pada tahun 2000 - 2001 diselesaikan melalui peringatan informal yang diberikan oleh pihak kepolisian, $27 \%$ peringatan tertulis, $32 \%$ program diversi dan $8 \%$ melalui family groups confereence. ${ }^{15}$ Catatan menarik yang dibuat oleh Gabrielle Maxwell adalah bahwa $25 \%$ dari jumlah pelaku yang mengikuti program Family Group Conference adalah para pelaku kejahatan serius seperti pembunuhan atau pembunuhan berencana. ${ }^{16}$

\section{B. Philippina}

di Philippina pun pendekatan keadilan restoratif (termasuk didalamnya dengan konsep Barangay) utamanya dipakai untuk penanganan perkara pidana oleh anak. Dalam hal ini, penanganan tersangka anak terkait dengan program pengentasan kemiskinan dan perlindungan hak-hak anak. Latar belakang pengintegrasian program tersebut adalah bahwa dari 75,6 juta penduduk Philippina, setengah diantaranya adalah anak-anak usia 18 tahun ke bawah. Dalam regulasi yang berlaku, batasan umur dimana seorang anak dapat di mintai

${ }^{13}$ G. Maxwell dan H. Hayes., Op. Cit., hal. 129.

${ }^{14}$ Ibid.

${ }^{15}$ Ibid.

${ }^{16}$ Ibid. 
pertanggungjawaban pidana adalah 9 tahun. Sementara itu pelaku tindak pidana anak memiliki karakteristik sebagai berikut: ${ }^{17}$

1. pelaku biasanya adalah anak laki-laki berusia 14-17 tahun;

2. Putus sekolah;

3. Pengangguran;

4. Datang dari keluarga dengan tingkat penghasilan rendah;

5. Tinggal didaerah pinggiran yang kumuh dan padat.

6. Beberapa diantaranya berasal juga dari keluarga yang berantakan.

7. Kejahatan yang dilakukan umumnya kejahatan di bidang harta benda seperti pencurian, narkotika dan psikotropika, beberapa diantaranya terlibat 'gang, kejahatan dan peredaran narkotika, dan penganiayaan dengan korban yang juga anak.

Kenyataan ini juga diperkuat dengan fakta bahwa ribuan anak Philippina yang berkonflik dengan hukum ditempatkah dalam lembaga pemasyarakatan atau pusat rehabilitasi. ${ }^{18}$ Akan tetapi hingga tahun 2003, Philippina tidak memiliki penjara yang khusus diperuntukkan untuk anak. Anak harus berbagi tempat dengan para nara pidana dewasa dan dengan fasilitas yang menurut Antonio, direktur eksekutif FREELAVA (the Free Rehabilitation, Economic, Education and Legal Assistance Volunteers Association, Inc Cepu Philippina) masih jauh dari memadai. ${ }^{19}$ Di penjara-penjara yang ada pemerintah hanya menyediakan dana Pph 30.00 (US\$.60)perorang perhari. ${ }^{20}$ Tidak ada fasilitas kesehatan, dokter gigi atau psikolog bagi anak. ${ }^{21}$ Hal yang paling mencemaskan adalah tingginya resiko terjadinya kekerasan oleh nara pidana dewasa kepada nara pidana anak.

Kenyataan tersebut menyebabkan FREELAVA pada tahun 1997 membuat dua buah proyek yang disebut "The Balay Pasilungan

${ }^{17}$ Antonio c, Local Initiatives on Divertion and Restoratif Justice for Children In Conflict with the Law - Philippine Experience, Jakarta, Hotel Inter-Continental Mid Plaza, 11 Desember 2203, hal. 2.

${ }^{18}$ Estimasi tahun 2003, terdapat sekitar 25.000 anak. Data di penjara Cebu misalnya tinggal 200 anak yang didakwa melakukan berbagai tindak pidana, mulai dari tindak pidana ringan seperti pencurian ringan sampai dengan tindak pidana yang berat seperti pembunuhan berencana, perampokan hingga perkosaan, C.Antonio, Op. Cit., hal. 2.
${ }^{19} \mathrm{Ibid}$.
${ }^{20} \mathrm{Ibid}$.
${ }^{21}$ Ibid. 
Project" dan "Community Based Diversion Program" pada tahun 2001. Proyek ini merupakan upaya perlindungan kepada anak-anak yang berkonflik dengan hukum.

\section{Balay Pasilungan}

Sesuai dengan namanya yang berarti rumah atau shelter, proyek ini bertujuan untuk menyediakan shelter sementara bagi anak-anak yang berkonflik dengan hukum.

\section{Community Based Diversion Program}

Merupakan program rehabilitasi bagi anak-anak narapidana yang baru bebas dari penjara. Program ini lebih melihat kepada peran serta masyarakat dalam membina anak-anak pelaku tindak pidana, sehingga mereka tidak terlalu lama berada dan menjalani proses peradilan pidana peran serta masyarakat dalam institusi masyarakat yang paling kecil seperti desa misalnya dimana ikatan dan kontrol sosial dapat dilaksanakan akan mampu memberikan pembinaan yang lebih baik dibandingkan dengan lembaga dalam sistem peradilan pidana.

Pelaksaan gagasan ini ditandai dengan Community Diversion Initiative yang disponsori oleh Save the Children-UK dan UNICEF di Philippina. Secara spesifik kegiatan ini bertujuan untuk:

(1) Meminimalisir penanganan kasus-kasus tindak pidana anak ke dalam sistem peradilan pidana

(2) Menawarkan mediasi sebagai upaya alternatif penyelesaian perkara pidana;

(3) Memperhatikan dan menerapkan dua prinsip dasar dari hak anak yang terumuskan dalam Konvensi hak anak yaitu the best interest of the child dan custodial facility should be made as the last recourse for the child and in the shortest possible time.

Proyek yang berlangsung sejak tahun 2001 ini memilih 12 desa percontohan dan melibatkan berbagai pihak seperti:

(1) Pemerintah daerah;

(2) Relawan dari warga;

(3) Anak mantan tersangka pelaku tindak pidana;

(4) Orangtua atau wali dari anak tersebut; 
(5) Pihak terkait lainnya seperti sekolah, organisasi keagamaan, polisi, lembaga swadaya masyarakat dan lain sebagainya.

Program ini benar-benar mengandalkan keterlibatan masyarakat sebagai pelaku utama dalam mengimplementasikan semua ide dalam kegiatan ini, khususnya anggota masyarakat yang telah bersedia untuk menjadi relawan. Untuk mendukung hal tersebut bagi mereka disediakan satu pelatihan khusus. Merekalah yang menjadi penggerak, fasilitator sekaligus evaluator dari kemajuan yang dicapai oleh anak yang menjalani program ini. Disamping kegiatan ini juga dipantau oleh FREELAVA sebagai organisasi penyelenggara.

Evaluasi yang dilakukan mencakup perubahan perilaku anak dalam keluarga dan masyarakat, kemajuan akademik di sekolah. Metode wawancara dengan semua pihak dipakai sebagai cara dalam melakukan evaluasi. Paradigma keadilan restoratif membuka wacana baru bagi hakim dalam membuat putusannya. Bila diatas sudah dinyatakan bahwa definisi dari diversi adalah pengalihan dari proses peradilan pidana kepada upaya lain sebelum persidangan, maka dalam hal ini diversi dimaknai lebih luas, termasuk juga putusan hakim untuk mengalihkan jenis pemidanaan.

Di Philippina, berkaitan dengan program "Balay Pasilungan" sebagaimana telah diuraikan diatas, maka dalam perkembangannya program ini diperluas. Bila sebelumnya "Balay Pasilungan" hanya menampung anak-anak mantan nara pidana, maka berdasarkan putusan hakim, para terdakwa anak dapat dimasukkan dalam lembaga ini sebagai alternatif pidana yang dirasakan lebih baik daripada memasukkan anak-anak tersebut ke penjara.

Dalam hal ini inisiatif pelaksanaan diversi murni berdasarkan pertimbangan hakim. Karenanya, berdasarkan pantauan FREELAVA, faktor-faktor yang menjadi dasar pertimbangan dalam menentukan apakah seorang anak dapat diikutsertakan dalam "Balay Pasilungan" adalah: ${ }^{22}$

(1) Latar belakang anak yang berkaitan dengan perkara;

(2) Mempertimbangkan lokasi pelaksanaan yang dapat menunjang proses rehabilitasi yang bertujuan untuk mereintegrasikannya kembali kepada masyarakat; 
(3) Laporan penelitian kasus yang menjadi dasar dari rekomendasi bagi pekerja sosial yang menanganinya;

(4) Anak mengikuti program ini atas dasar kesukarelaan dan bukan didasarkan atas paksaan;

(5) $\mathrm{Si}$ anak sepenuhnya dapat mengerti tentang program yang dia ikuti termasuk juga tanggungjawab yang harus diembannya, keluarga dan korban;

(6) Persetujuan dari korban bahwa si anak akan ikut didalam program ini.

Dalam evaluasi yang diselenggarakan oleh FREELAVA, tercatat sejumlah keuntungan dari penyelenggaraan diversi di tingkat pengadilan yaitu bahwa program ini dapat membantu:

(1) membebaskan terdakwa (dalam hal ini adalah anak) dan juga hakim dan mereka yang terlibat di dalamnya dari suatu proses yang panjang dan melelahkqn serta membebaskan dari dampak negatif yang ditimbulkannya seperti trauma.

(2) mereduksi dan membebaskan anak dari dampak negatif yang timbul dari suatu pemidanaan.

(3) mendorong anak untuk mengerti arti dari suatu tanggungjawab atas kerusakan yang timbul dan korban dan bersedia mengemban tanggungjawab itu.

(4) mendorong masyarakat dan korban untuk berpartisipasi dalam usaha membina pelaku untuk mau berubah untuk memperbaiki diri atau membayar kerusakan yang timbul.

\section{Dilema Penerapan Diversi di Indonesia}

Lembaga Diversi di Indonesia dalam kenyataannya bukan merupakan hal yang sulit dicari dalam praktek penegakan hokum, akan tetapi permasalahan terbesar dalam penggunaan lembaga ini adalah kegamangan petugas kepolisian akan keabsahannya. Hasil penelusuran penulis baik berdasarkan kajian pustaka maupun penelusuran dilapangan menghasilkan gambaran sebagai berikut:

\section{Dilema Polisi}

Pilot Project Pelaksanaan Pendekatan Keadilan Restoratif di kota Bandung yang telah berjalan beberapa tahun terakhir barangkali merupakan angin segar bagi perubahan paradigma petugas dalam menangani perkara pidana anak. Temuan dalam disertasi Marlina dalam Disertasinya tentang Pendekatan 
Restoratif bagi Anak Yang Berhadapan dengan Hukum menyatakan bahwa telah terjadi perubahan pandangan petugas penegak hukum dalam menangani perkara pidana antara lain 55\% informan (yang berasal dari penegak hukum berpendapat bahwa terhadap anak yang melakukan tindak pidana tidak dilakukan penangkapan) sedangkan $45 \%$ informan berpendapat terhadap anak dilakukan penangkapan. Dari fakta ini disimpulkan bahwa komponen aparat pengak hukum tersebut telah menyadari terhadap anak pelaku tindak pidana harus diberikan perlindungan demi perkembangan kejiwaannya. Ketika melihat anak yang melakukan tindak pidana polisi bersikap untuk tidak melakukan penangkapan. Polisi hanya memberikan nasehat dan peringatan kepada pelaku dan orang tua pelaku. Nasehat tersebut diberikan polisi sebagai langkah awal untuk proses penyelesaian secara kekeluargaan atau perdamaian.

Akan tetapi gambaran yang diberikan Marlina dalam disertasinya tersebut barangkali harus dilihat kembali secara kritis. Bila mengacu pernyataan dari AKP Edison Harefa, Ketua Unit Remaja, Anak dan Wanita (Renakta) Kepolisian Daerah Jawa Barat yang dimuat di dalam wawancara pada Buletin Restorasi edisi 9 yang menyatakan bahwa masih banyak dilakukannya penahanan terhadap anak. ${ }^{23}$ Pandangan ini barangkali tidak terlalu keliru mengingat tidak tersedianya rumah tahanan khusus anakanak. Bahkan penahanan ini masih disatukan dengan ruang tahanan dewasa karena belum adanya ruang penahanan khusus untuk anak. ${ }^{24}$ Kondisi yang demikian tentunya rentan terhadap pelanggaran hak-hak anak dan sulitnya memenuhi hak mereka. Yang dapat dilakukan oleh petugas kepolisian dalam hal ini adalah tidak melakukan penahanan terhadap tersangka anak selama proses pemeriksaan, melainkan dikembalikan kepada orangtua atau ke panti sosial milik Dinas Sosial Pemerintah Daerah dalam hal anak-anak yang tidak memiliki orangtua. ${ }^{25}$

Keluhan tidak tersedianya ruang tahanan khusus anak juga dijumpai penulis didaerah Kupang, dimana petugas kepolisian

${ }^{23}$ AKP Edison Harefa: Kita Tidak Ada Aplikasi di Lapangan, Buletin Restorasi, Edisi 9/Volume IV tahun 2008, hal. 47-48.

${ }^{24}$ Ibid.

2008.

${ }^{25}$ Wawancara dengan Petugas Kepolisian Polwiltabes Bandung tanggal 29 Maret 
justru menitipkan seorang tahanan anak ke sebuah gereja yang bersedia menampungnya (meskipun si anak beragama Islam). ${ }^{26}$ Kebijakan ini diambil semata-mata dengan pertimbangan bahwa kondisi di gereja masih jauh lebih baik daripada dalam ruang tahanan. Temuan ini menegaskan bahwa pendekatan restoratif dalam kerangka diversi telah dilakukan tanpa menunggu suatu gerakan atau kebijakan tertentu dari pemerintah.

Pandangan bahwa suatu proses perkara pidana yang sudah masuk dalam sistem harus tuntas hingga ke pengadilan agaknya masih dianut oleh para petugas penegak hukum. ${ }^{27}$ Akan tetapi dalam pola penanganan terhadap pelaku anak di Bandung, para petugas kepolisian mengaku mereka lebih berhati-hati dan berupaya sedapat mungkin dan secepat mungkin melakukan proses dan melimpahkannya kepada Jaksa untuk dilakukan penuntutan. ${ }^{28}$

\section{Mediasi Hakim-Jaksa}

Para informan menilai upaya mediasi sebagai jalan yang dapat ditempuh untuk menyelesaikan suatu perkara pidana bukan merupakan mekanisme yang dikenal dalam hukum pidana. Karenanya upaya ini tidak pernah mereka terapkan dan mereka tempuh. Mediasi memang dikenal dan diterapkan di pengadilan negeri Bandung, akan tetapi makna mediasi yang diterapkan tidak sama dengan konsep mediasi yang dikenal dalam hukum perdana. Mediasi di Pengadilan Negeri Bandung hanya diterapkan untuk kasus perkara pidana oleh anak. ${ }^{29}$ Dalam hal ini mediasi adalah pertemuan yang dilakukan antara pihak terdakwa dan keluarganya, Petugas Bapas, Penuntut Umum dan Hakim. Tujuan

Agustus 2007.

${ }^{26}$ Wawancara dengan petugas kepolisian dari Kapolwiltabes Kupang pada 5

${ }^{27}$ Wawancara dengan informan Polisi di Jakarta 22 - 25 Februari 2006, Denpasar Wawancara pada 5 Juni 2007 di Denpasar dan Bandung, 29 Maret 2008. Ditegaskan pula oleh AKP Edison Harefa, Op. Cit.

28 Wawancara dengan informan Polisi di Jakarta 22 - 25 Februari 2006, Denpasar Wawancara pada 5 Juni 2007 di Denpasar dan Bandung, 29 Maret 2008.

29 Wawancara dengan hakim PN Bandung pada tanggal 29 Maret 2008 dan dikuatkan oleh Narasumber Ibu Emmy Marni, wawancara pada 21 April 2008 yang menyatakan bahwa model ini juga dipraktekkan di PN Menggala-Lampung. 
dari pertemuan ini adalah untuk menentukan hal-hal apa yang perlu diperhatikan dan disepakati sepanjang pemeriksaan dalam sidang pengadilan. Utamanya bila hakim berkehendak untuk menjatuhkan sanksi tindakan atau pidana minimal. Belajar dari pengalaman bahwa sanksi minimal biasanya menjadi percuma karena Jaksa akan melakukan upaya hukum, maka dalam pertemuan ini hakim meminta kesediaan jaksa untuk tidak terlalu tinggi mencantumkan tuntutan dan bersedia untuk tidak melakukan upaya hukum. Hal ini diperlukan untuk menjamin bahwa proses peradilan pidana yang dijalani oleh anak secara singkat dan cepat. Hasil dari proses kesepakatan hakim dan jaksa ini dapat dilihat dengan membandingkan putusan hakim dengan jumlah tuntutan jaksa dalam perkara pidana anak di PN Bandung pada tahun 2007. Berikut 5 putusan PN Bandung sebagai contoh perbandingan tersebut:

Tabel. 21

Perkara di PN. Bale Bandung Tahun 2008

\begin{tabular}{|c|c|c|c|}
\hline No.Perkara & Perkara & Tuntutan & Vonis \\
\hline $\begin{array}{l}\text { 01/Pid.an/2007/ } \\
\text { PN.Bdg }\end{array}$ & $\begin{array}{l}\text { Pelanggaran Pasal } \\
363 \text { KUHP an. } \\
\text { Mulyadi Bin Udin } \\
\text { Sanjaya }\end{array}$ & $\begin{array}{l}\text { Pidana } \\
\text { Penjara } \\
\text { selama } 4 \\
\text { bulan } \\
\text { dikurangi } \\
\text { masa } \\
\text { tahanan. }\end{array}$ & $\begin{array}{l}\text { Pidana penjara } \\
\text { selama } 3 \text { bulan } \\
\text { dikurangi masa } \\
\text { tahanan. }\end{array}$ \\
\hline $\begin{array}{l}\text { 02/Pid.an/2007/ } \\
\text { PN.Bdg }\end{array}$ & $\begin{array}{l}\text { Pelanggaran Pasal } \\
78 \text { (1)a UU No. } 22 \\
\text { th. } 2007 \text { an. M. } \\
\text { Nufery bin } \\
\text { Mamin }\end{array}$ & $\begin{array}{l}\text { Pidana } \\
\text { Penjara } \\
\text { selama } 8 \\
\text { bulan } \\
\text { dikurangi } \\
\text { masa } \\
\text { tahanan. }\end{array}$ & $\begin{array}{l}\text { Tindakan dengan } \\
\text { cara } \\
\text { mengembalikan } \\
\text { kepada orangtua } \\
\text { untuk diasuh, } \\
\text { dididik dan dibina } \\
\text { dibawah } \\
\text { pengawasan } \\
\text { BAPAS }\end{array}$ \\
\hline $\begin{array}{l}\text { 03/Pid.an/2007/ } \\
\text { PN.Bdg }\end{array}$ & $\begin{array}{l}\text { Pelanggaran Pasal } \\
82 \text { UU No. } 23 \\
\text { Tahun } 2002 \text { an. } \\
\text { Rahman Agus } \\
\text { Salim, Wahyudin }\end{array}$ & $\begin{array}{l}\text { Pidana } \\
\text { Penjara } \\
\text { selama } 6 \\
\text { tahun dan } \\
\text { denda Rp. } 60\end{array}$ & $\begin{array}{l}\text { PN: Pidana Penjara } \\
\text { selama } 10 \text { bulan } \\
\text { dan denda Rp. } 60 \\
\text { juta subsider } 20 \\
\text { hari kerja dikurangi }\end{array}$ \\
\hline
\end{tabular}




\begin{tabular}{|c|c|c|c|}
\hline & $\begin{array}{l}\text { bin Asep Hardi } \\
\text { dan Asep Taryana } \\
\text { Bin Tardin }\end{array}$ & $\begin{array}{l}\text { juta subsider } \\
20 \text { hari kerja } \\
\text { dikurangi } \\
\text { masa tahanan }\end{array}$ & $\begin{array}{l}\text { masa tahanan. } \\
\text { Kasasi: } \\
\text { Menyerahkan } \\
\text { terdakwa kepada } \\
\text { negara untuk } \\
\text { mengikuti } \\
\text { pendidikan, } \\
\text { pembinaan dan } \\
\text { latihan kerja }\end{array}$ \\
\hline $\begin{array}{l}\text { 04/Pid.an/2007/ } \\
\text { PN.Bdg }\end{array}$ & $\begin{array}{l}\text { Pelanggaran Pasal } \\
81 \text { (1) UU No.23 } \\
\text { th.2002, Pasal } \\
285,286,287 \text { jo. } 55 \\
\text { KUHP } \\
\text { An. Asep ahmad } \\
\text { Jaeni dan } \\
\text { Ginanjar } \\
\text { Mardianto }\end{array}$ & $\begin{array}{l}\text { Pidana } \\
\text { Penjara } \\
\text { selama } 6 \\
\text { tahun dan } \\
\text { denda Rp. } \\
\text { 60.juta } \\
\text { subsider } 20 \\
\text { hari kerja } \\
\text { dikurangi } \\
\text { masa tahanan }\end{array}$ & $\begin{array}{l}\text { Pidana Penjara } \\
\text { selama } 3 \text { tahun dan } \\
\text { denda Rp. } 60 \text { juta } \\
\text { subsider } 20 \text { hari } \\
\text { kerja dikurangi } \\
\text { masa tahanan. } \\
\text { Banding dan Kasasi } \\
\text { : Ditolak. }\end{array}$ \\
\hline $\begin{array}{l}\text { 05/Pid.an/2007/ } \\
\text { PN.Bdg }\end{array}$ & $\begin{array}{l}\text { Pelanggaran Pasal } \\
351 \text { KUHP } \\
\text { an.Dono } \\
\text { Gomgom P }\end{array}$ & $\begin{array}{l}\text { Pidana } \\
\text { Penjara } \\
\text { selama } 6 \\
\text { bulan } \\
\text { dikurangi } \\
\text { masa tahanan } \\
\end{array}$ & $\begin{array}{l}\text { Pidana Penjara } \\
\text { selama } 3 \text { bulan } 7 \\
\text { hari dikurangi masa } \\
\text { tahanan }\end{array}$ \\
\hline
\end{tabular}

Dari contoh tersebut terdapat 3 perkara dimana jaksa menerima putusan hakim hingga tidak dilakukan upaya hukum, sementara dalam perkara no.3, jaksa melakukan upaya kasasi karena menganggap putusan hakim terlalu rendah dimana tuntutan jaksa 6 tahun penjara sementara hakim hanya menjatuhkan 10 bulan penjara, akan tetapi hakim Mahkamah Agung justru menjatuhkan tindakan dengan menempatkan anak sebagai anak negara. Satu putusan yaitu perkara no.4, upaya hukum justru dilakukan oleh terdakwa dan keluarga karena menganggap putusan hakim terlalu tinggi, akan tetapi baik ditingkat banding maupun kasasi upaya hukum tersebut ditolak.

Sebagaimana disampaikan oleh informan hakim di Pengadilan Negeri Bandung, proses mediasi ini tidak selamanya berjalan mulus, karena tidak selamanya pihak jaksa ataupun terdakwa dan keluarganya menerima tawaran hakim tentang jenis 
dan berat sanksi yang akan dijatuhkan. Hal ini disebabkan karena Jaksa memiliki ketentuan tersendiri atas penanganan suatu perkara pidana yang terkait dengan penilaian atas kinerja mereka.

\section{Diversi oleh Hakim}

Pilihan penjatuhan jenis pidana atau tindakan terlihat dicoba diterapkan di Bandung. Mengenai implementasi dari tindakan berupa kerja selama waktu tertentu sebagai pengganti denda, atau pembinaan oleh Bapas, mengingat sarana dan prasarana terbatas yang dimiliki lembaga ini, maka inovasi yang dilakukan oleh hakim adalah menjalin kerjasama dengan dinas sosial Pemerintah daerah kota Bandung. Salah satu contoh kasus yang dikemukakan oleh informan adalah kasus Eka, seorang gadis yang melakukan tindak pidana perbuatan cabul terhadap sesama jenis (No. Perkara No. 46/Pid.an/2008/PN Bdg). Hakim yang mengadili menjatuhkan sanksi tindakan kepada Eka Purnama Sari bin Kurnia Sanusi dengan mengembalikan anak nakal kepada orangtuanya di bawah pengawasan petugas Balai Pemasyarakatan (BAPAS Bandung). Namun mengingat kondisi Bapas dan Orangtua korban yang dinilai hakim kurang untuk melakukan pembinaan maka hakim mengupayakan agar Eka dimasukkan dalam program pengentasan kemiskinan yang dilakukan oleh Departemen Sosial melalui Dinas Sosial. ${ }^{30}$ Apa yang dilakukan oleh hakim yang menangani perkara Eka ini mengingatkan pada program Katurangan Barangay di Phillipina. Program ini dikaitkan dengan pengentasan kemiskinan mengingat karakteristik umum yang ditemukan di dalam pelaku tindak pidana anak di Philipina. Kesulitan hakim untuk memberikan tempat bagi korban lebih dari prosedur yang ditetapkan dalam hukum acara pidana yang berlaku, termasuk mengenai gantirugi,restitusi dan kompensasi.

Sebagaimana proses mediasi yang terjadi di Pengadilan Negeri Bandung yang belum memberikan tempat kepada korban, maka dalam proses peradilan pidana di Indonesia, korban bukanlah pihak yang dapat ikut menentukan hasil dari proses peradilan pidana yang berjalan. Korban hanya ditempatkan sebagai pelengkap penderita yaitu salah satu alat bukti yang dapat dipakai untuk menggiring pelaku kearah pertanggungjawaban pidana beupa sanksi yang ditentukan undang-undang. Apakah

${ }^{30}$ Wawancara dengan informan Hakim Bandung, 29 Maret 2008. 
sanksi yang dijatuhkan memberikan keuntungan kepada korban atau tidak, hal demikian bukan merupakan bagian dari pertimbangan yang harus dilakukan hakim.

\section{Penutup}

Meskipun terjadi kegamangan dalam proses penerapan diversi oleh petugas penegak hukum, upaya mencari bentuk penerapan penanganan perkara pidana anak sudah menjadi suatu wacana yang berkembang. Ketiga ilustrasi kasus diawal tulisan ini mungkin bukan merupakan contoh yang baik dari petugas penegak hukum yang berfikir secara "legalistis". Akan tetapi tidak dapat dipungkiri bahwa tanpa adanya mekansme yang jelas keabsahannya oleh aturan perundnag-undangan, petugas penegak hokum baik polisi, jaksa maupun hakim merasa gamang dalam menjalankan tugasnya, terutama apabila mereka melihat bahwa langkah yang sah menurut hokum belum tentu baik diterapkan di lapangan. Kebijakan penanganan perkara pidana melalui lembaga diversi bukan hanya menjadi tuntutan bagi petugas penegak hokum dilapangan, akan tetapi juga harus dilembagakan melalui mekanisme hukum acara yang jelas. Semoga penggunaan sarana hokum pidana sebagai suatu Ultimum Remedium dapat diimplementasikan sesuai dengan fungsinya. 


\section{Daftar Pustaka}

Abdillah, Sandi Ibrahim., Antara Pengusiran dan Pemenjaraan, Jurnal Restorasi Edisi 9 Vol. IV Tahun 2008.

Antonio c, Local Initiatives on Divertion and Restoratif Justice for Children In Conflict with the Law - Philippine Experience, Jakarta, Hotel InterContinental Mid Plaza, 11 Desember 2003.

Aronson, David E., Thomas Dienes dan Machael C. Musheno., Public Policy And Police Discretion Processes of Decriminalization, New Cork: Clark Boardman CO, 1984.

BPHN, Draft Akademis RUU Peradilan Anak, (Jakarta: BPHN,2007), definisi ini juga terdapat dalam Manual Pelatihan Untuk Polisi, Proyek Kerjasama UNICEF dan POLRI, 2004.

Garner, Bryan A. (ed), Black's Law Dictionary, Minnessota: St.Paul, 2000.

Harefa, AKP Edison., Kita Tidak Ada Aplikasi di Lapangan, Buletin Restorasi Edisi 9/Volume IV tahun 2008.

Heffernan, William C dan Timothy Stroup (eds), Police Etics: Hard Choices in Law Enforcement, New York: John Jay Press, 1985.

Marlina, Pendekatan Restoratif bagi Anak Yang Berhadapan dengan Hukum, Disertasi Pada Program Doktor Universitas Sumatera Utara, 2004.

Ministery of Social Develompent, Safeguarding our children: Updating the Children, Young Persons, and their Families Act 1989, WellingtonNew Zealand, 2 Agustus 2007.

Ness, Daniel van, Allison Morris dan Gabriel Maxwell, Introducting Restorative Justice dalam, Allison Morris dan Gabrielle Maxwell (editor), Restorative Justice for Juveniles: Conferencing, Mediation and Circles, Oxford: Hart Publishing, 2001.

Ness, Daniel Van., An Overview Restortive Justice Around The World, makalah disampaikan pada United Nation $11^{\text {th }}$ congress on Crime Prevention and Criminal Justice, Bangkok Thailand, 22 April 2005.

Wright, Ronald F dan Rodnef F. Langen., The Effective Of Depth and Distance in a Criminal Code on Charging, Sentencing And ProsecutorPower, North California Law Review Vol. 84 tanggal 15 September 2006.

Youth Justice and Criminal Evidence Act, 1999, UK Parliament. 